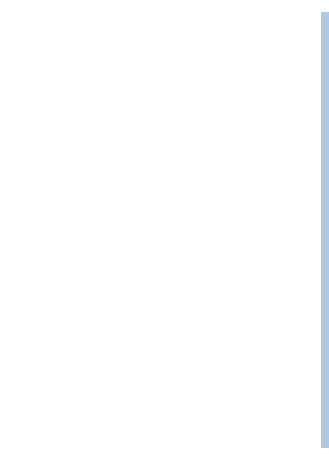

Jafarli J. V.
Journal of Geology. Geography and

Journal home page: geology-dnu.dp.ua
Journ. Geol. Geograph.

Geology,
$30(4), 675-682$.
doi: $10.15421 / 112162$

Geology,
$30(4), 675-682$.
doi: $10.15421 / 112162$

ISSN 2617-2909 (print)

ISSN 2617-2119 (online)

\title{
Impact of anthropogenic activity on the chemical regime of underground waters
}

Jale V. Jafarli

Baku State University, Azerbaijan Republic,Baku, j.gzade@hotmail.com

Received: 24.05.2021

Received in revised form: 20.07.2021

Accepted: 08.09.2021

Abstract. The article is dedicated to definition of the tendency to change and pattern of formation of the chemical regime of underground waters in the Turyanchay-Girdimanchay interfluve in the Shirvan steppe, Azerbaijan as a result of anthropogenic activity. The subsoil waters studied are spread in the zone between the Turyanchay and Girdimanchay rivers. From 1930 to 2019 based on analysis of the observation of the chemical regime of subsoil waters, the natural regime of the groundwaters in the studied area strongly changed as a result of irrigation and construction works. In 1930 the average mineralization degree of subsoil waters was 26.8 gram/liter in the zone. The level of subsoil waters approaches the surface and is exposed to strong evaporation as a result of irrigation and filtration of waters from irrigation channels. Consequently, the mineralization rate of subsoil waters increased and mass secondary salinization process occurred in the irrigated lands. The average mineralization degree of subsoil waters was 33.6-34.5 gram/liter in the research zone in the 1960s-1970s. Collector-drainage networks were built and basic washing of soils is carried out in order the prevent secondary salinization and regulate the level of subsoil waters. After the 1970s the mineralization rate of subsoil waters began to decrease due to basic washing, intensive irrigation and the activity of the collector-drainage network. The average mineralization degree decreased to $15.1 \mathrm{gram} /$ liter. The mineralization degree of the water in the Main Shirvan Collector which takes subsoil waters formed in the zone with 253,000 hectares and which discaharges them into the Caspian Sea decreased more than 3 times in comparison with 1995. At present the mineralization degree of collector water is $1.8-2.5$ gram/liter while its mineralization degree was 8.81 gram/liter in 1995. Formation of the process in a favourable direction enchances the potential of using collector water for irrigation, technical and other purposes and creates a basis for elimination of water deficiency in drought years. The research shows that anthropogenic activity mainly plays an important role in formation of the chemical regime of subsoil waters.

Keywords: anthropogenic activity, underground waters, chemical regime, reduction, tendency, formation, mineralization rate.

\section{Вплив антропогенної діяльності на хімічний режим грунтових вод}

\author{
Жаля В. Джафарлі
}

Бакинський Державний Університет Азербайджанська Республіка, Баку, j.gzade@hotmail.com

Анотація. Стаття присвячена питанню встановлення тенденції зміни та закономірності формування хімічного режиму грунтових вод, що залягають на території Туріанчай - Гирдиманчайського межиріччя Ширванського степу Азербайджану. На основі аналізу спостережень за хімічним режимом грунтових вод, проведених у 1930-2018 р.р. встановлено, що в результаті здійснення широкомасштабних іригаційно-будівельних робіт докорінно змінився природний режим грунтових вод на досліджуваній території. Так, у 1930 р. середня мінералізація грунтових вод становила 26,8 г/л, а глибина їх залягання - понад 5-10 м. Однак за рахунок інтенсивного зрошення та фільтрації з зрошувальних каналів, побудованих у земляному руслі, сприяли підйому рівня грунтових до денної поверхні та в результаті якого сталося сильне випаровування з їхньої поверхні. Це у 1960-1970 р.р. призвело до підвищення мінералізації грунтових вод до 33,6-34,5 г/л та до масового вторинного засолення земель. Для боротьби з вторинним засоленням земель та запобігання цьому явищу здійснено будівництво колекторно-дренажної мережі та проведено капітальне промивання засолених грунтів. За рахунок капітального промивання, інтенсивного зрошення та завдяки діям колекторно-дренажної мережі, після 1970 року відбувалося поступове зниження мінералізації грунтових вод. Встановлено, що під впливом господарської діяльності відбувається поступове опріснення води Головного Ширванського колектора, в який впадають стоки 29 первинних колекторно-дренажних мереж, що дренують грунтові води на площі 253 тис. га. Якщо мінералізація води Головного Ширванського каналу 1995 р. становила 8,81 г/л, то до кінця 2018 року вона стала 1,8-2,5 г/л. Формування сприятливого хімічного режиму стоку колектора, грунтових вод створюють умови використання їх з метою зрошення, технічних та інших потреб під час посухи та в умовах дефіциту поверхневих вод. Дослідження показують, що хімічний режим грунтових вод даної території загалом формується переважно під впливом антропогенних чинників, тобто. господарської діяльності людини.

Ключові слова: антропогенна діяльність, трунтова вода, хімічний режим, зниження, тенденція, формування, мінералізація. 


\section{Introduction.}

Serious disruption of the ecological balance as a result of anthropoghenic and natural impacts on the environment is observed in recent times. Unplanned and unscientific interventions on the earth's surface, for example, an example, an excessive expoitation of the underground resources (underground water sources), large-scale construction works works of various purposes, deforestation, destruction of natural landcapes, climate changes and other similar situations have led to creation of some disturbances, including changes of the hydrogeological conditions.

Research indicates that excessive use of underground waters in Ganja-Gazakh and Garabagh regions has caused depletion of their reserves while in other regions, such as the Shirvan Mughan and Mil plains, the construction of large-scale irrigationmelioration systems have caused change in the level and chemical regime of underground waters. Identification of tendencies to change in the chemical regime in subsoil waters and formation regularities under such condition is of particular importance in the context of developing preventive measures.

\section{Aim of the research.}

The aim of the research consists of definition of tendency to change and patterns of formation of the chemical regime in subsoil waters under anthropoghenic impacts in the zone between the Turyanchay and Girdimanchay rivers of the Shirvan region.

\section{Research object.}

The object is subsoil water which developed in the Quaternary sediments in the zone between the Turyanchay and Girdimanchay.

\section{Materials and method.}

The studies are based on the chemical analysis and results of analysis of water samples taken from fixed observation wells located in a chequer form every $2.5-5.0 \mathrm{~km}$ in the zone where the chemical regime of underground waters is investigated.

The factors affecting the change and formation of the chemical regime in underground waters have been determined on the basis of investigation of the melioration-irrigation works and farming activity carried out in the zone.

We used the account archive and fund materials (Abbasov, 2009; Abbasov, 2013; Namazov and Allahverdiyeva 2014; Aliyev et al., 1990) of the National Geological Expert Service of the Ministry of Environment and Natural Resources, HydrogeologicalMeliorative Service Department of the Open Joint Stock Company of Water Resources and Melioration-Irrigation in references dedicated to the problem of these materials
(Aliyev et al., 1990; Israfilov, 1999) and the result of the observation and experiments.

The chemical regime of underground waters in the research zone was studied on the basis of chemical regime of flow in the Main Shirvan Collector, which takes waters of the initial collectordrainage networks built for regulation of their level and sheds them into the Caspian Sea. In 20102018 the mineralization degree and ion composition $\left(\mathrm{HCO}_{3}^{-}, \mathrm{Cl}^{-}, \mathrm{SO}_{4}^{2-}, \mathrm{Ca}^{2+}, \mathrm{Mg}^{2+}, \mathrm{Na}^{+}+\mathrm{K}^{+}\right)$of water was fixed by subjecting the water samples taken from the Main Shirvan Collector in every season to the full chemical analysis.

So, the chemical regime of subsoil waters was studied on the basis of chemical analysis of the water samples taken from the Main Shirvan Collector which takes subsoil waters from the zone and observation wells located in the horizon carrying the subsoil waters from two sources.

\section{Analysis and discussions.}

The area of 320000 hectares is located in the central part of the Shirvan plain is 860000 h. (Fig.1). The research zone is bordered by the Great Caucasus Mountains to the North, by the Kur River to the south, by the Aghsu-Girdmanchay River to the West. The inclination of the surface changes from North to South. The absolute height of the plain part of the zone is $408 \mathrm{~m}$ in the North, but it is $26 \mathrm{~m}$ below sea level in the South. The annual quantity of rainfalls is $250-400 \mathrm{~mm}$, but the amount of evaporation is $800-1400 \mathrm{~mm}$. The average perennial temperature is $13-16^{\circ} \mathrm{C}$.

Recently, the amount of precipitation in the area has decreased by 27 , the value of the annual temperature increased by $-1,1-17^{\circ} \mathrm{C}$ (Mahmudov, 2017). Subsoil waters are spread everywhere in the zone. The riverbed depth of underground waters changes from $0.5 \mathrm{~m}$ to $5.0 \mathrm{~m}$ according to hydroisogypsum map and observation materials of 2019 (Gulmamedov and Jafarli, 2019) The river-bed depth of subsoil waters is $1-3 \mathrm{~m}$ in the areas with irrigation and drainage.

Change in the level and chemical regimes of underground waters in the research zone in the years 1930-1962 was investigated by H. Y. Israfilov (Israfilov, 1972; Israfilov 1965) and for 1950-1995 by A.K (AK is The High Attestation Commision) the regular observations on level and chemical regimes of subsoil waters were performed in the Republic, the generalization and systematization have not been performed in recent times. The information about the chemical regime of subsoil waters based on accounts of the previous materials and accounts of the Department of Hydrogeological-Meliorative Service in 1990-2018 was systematized and presented in Table 1. 


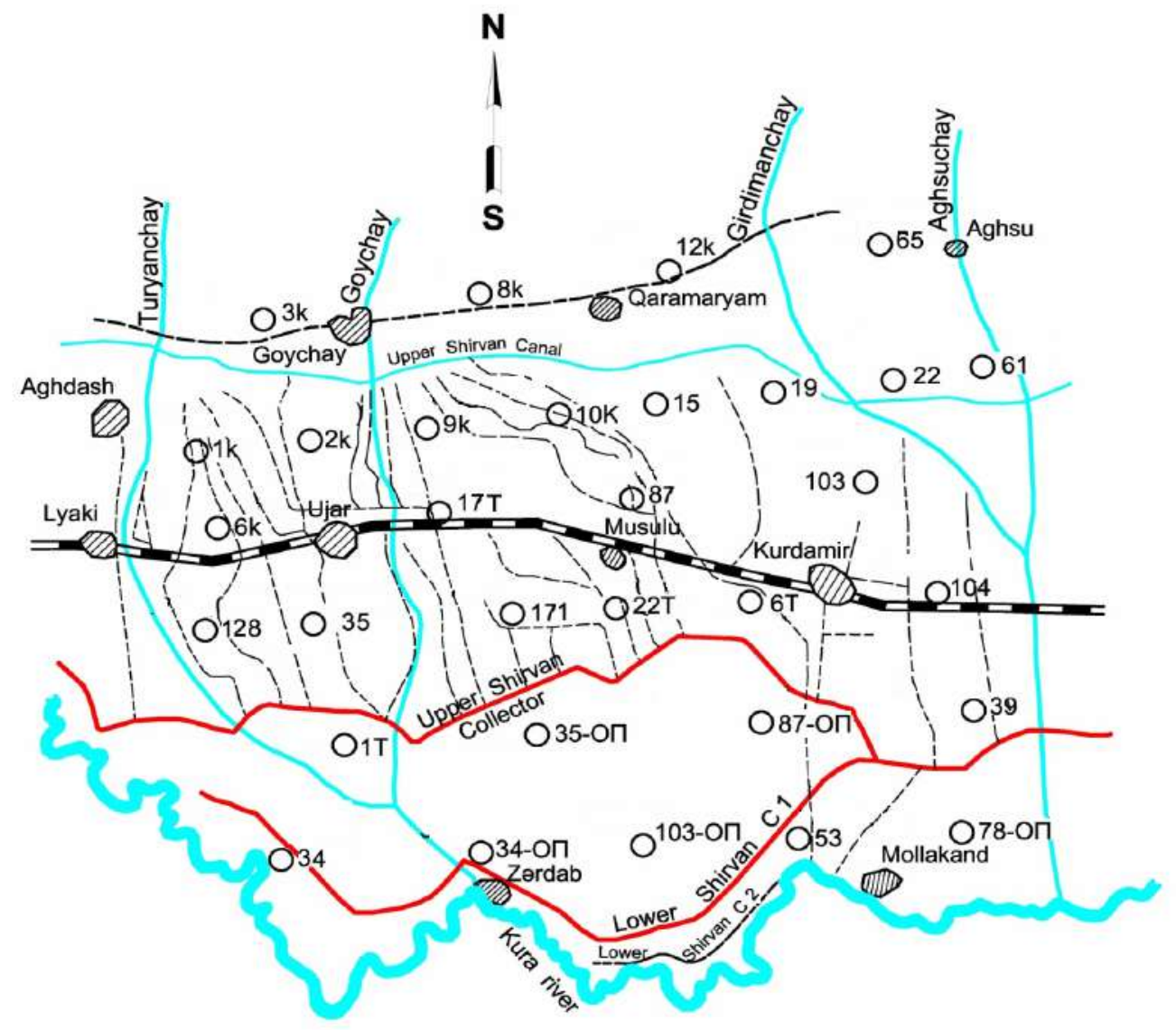

Fig. 1. Schematic Map of Turyanchay-Girdimanchay Interriver Area: 1-Collector drainage network; 2-River and irrigational system; 3-Observation wells and their number; 4-Residential settlement;5-Railway.

Groundwater is ubiquitous in Quaternary sediments in the Turyanchay-Girdimanchay interfluve area, but is not found in some foothill areas of interconal depressions. The depth of a deposit of subsoil waters varies from $0.5 \mathrm{~m}$ to $73 \mathrm{~m}$. The depth of a deposit of subsoil waters in the eastern part of the Girdimanchay river, in the upper part of the Agsu River is 30-40 m. The depth of groundwater in the Upper Shirvan channel and in areas with intensive irrigation varies between 1-3 m. Their depth decreases toward the south-west of the area and the Kura River and is drained by the river.

In the upper part of the area, a single layer of water is divided into several layers in the direction of subsoil water flow. However, this division is of local character and the groundwater in the area is represented by a single aquifer horizon. The slope of the subsoil waters flow varies between $0.03-0.0007 \mathrm{cms}$ and decreases from the foothills toward the plains. Due to the widespread distribution of alluvial-proluvial sediments in the areas where the alluvial (debris) cones are located, the aeration zone has a high water permeability. The thickness of the subsoil aquifer horizon varies from 5 to $178 \mathrm{~m}$. Its thickness in the foothills is $110-178 \mathrm{~m}$, and $5-10 \mathrm{~m}-$ in the plain areas.

The leakage coefficient of soils in the detrital cone of the Turyanchay River is higher than in the sediments of other rivers. Here, the value of the filtration coefficient of permeable rocks reaches to $4 \mathrm{~m} /$ day and mainly ranges between $1-3 \mathrm{~m} /$ day. In the peripheral parts of the alluvial cones and in the interconal depressions, the value of the filtration coefficient is confined to $0.2-0.5$ $\mathrm{m} /$ day. The filtration coefficient of aquifers varies from $0.1 \mathrm{~m} /$ day to $64.1 \mathrm{~m} /$ day and decreases successively from the beginning of the alluvial cones to the periphery. The said lithological differences have a permanent impact on the groundwater regime in the area.

Changes in groundwater water levels and chemical regimes in the study area occur under the influence of natural and anthropogenic factors. In general, various sources are involved in the formation of subsoil waters. These sources are divided into two parts, in turn- natural and artificial sources.

Natural sources include atmospheric sediments, water vapor condensation, pressurized water, floods, kariz (underground water supply system), springs, rivers, and parent rocks. Atmospheric sediments and condensation from these waters, which feed groundwater, are regional and local sources of supply.

Artificial groundwater sources include water losses from all types of channels and reservoirs, as well as infiltration from irrigational water. At the same time, the natural evaporation factor plays an important role in 
the formation of quantitative and qualitative indicators of groundwater sources. General evaporation includes evaporation from groundwater and water transpirated by vegetation.

Evaporation is one of the balancing elements of groundwater and plays a substantial role in the formation of their chemical regime, which is mainly a negative factor that leads to an increase in the degree of mineralization of groundwater and re-salinization of soils. Evaporation is also a key factor directly affecting the reduction of groundwater resources and reserves.

The analysis shows that there is a close relationship between the groundwater level regime (depth of deposition) and the hydrochemical regime (degree of salinity, chemical composition and type of water). In areas with low groundwater depth, the water mineralization rate increases, and in the case of deep groundwater levels, on the contrary, the mineralization rate decreases.

The chemical composition and type of groundwater distributed in the area varies drastically depending on the depth of their deposition and location (position). Here, the degree of mineralization of groundwater varies from fresh to saline and is subject to a certain regularity. In the upper parts of the supply cones of the Turyanchay, Goychay and Girdimanchay rivers, in the zone of groundwater formation, the mineralization rate of groundwater does not exceed $1 \mathrm{~g} / \mathrm{l}$. The salinity of groundwater begins to increase in the direction of the wings of the interconal depression and in the direction of the periphery of the alluvial cones, and in some cases the mineralization reaches $130 \mathrm{~g} / \mathrm{l}$. In this case, groundwater has different chemical types.

If the groundwater deposition level is deep, its type is sodium bicarbonate, and if it is close to the surface - chlorine-sulphate and sulphate-chlorine. In groundwater with a salinity up to $1 \mathrm{~g} / 1$, hydrocarbonate holds a leading position among anions, and sodium and calcium among cations. Rarely, magnesium predominates among cations. In groundwater with a salinity level $10-15 \mathrm{~g} / \mathrm{l}$, the amount of hydrocarbons decreases, the amount of chlorine and sulphate increases. These waters contain more sodium and magnesium than calcium. In groundwater with a salinity level 50-100 $\mathrm{g} / \mathrm{l}$ and more, a decrease in sulphate is accompanied by an increase in chlorine, and in some cases, a decrease in chlorine and an increase in sulphate.

As a result of reclamation and irrigation measures carried out in the study area, there have been many and seasonal changes in groundwater level and hydrochemical regimes, and the process is currently underway. First of all, let's have a look at the regularity of the formation of the multi-level regime of groundwater.
The outcomes of analysis of the materials show that at the beginning of the last century, the irrigation capacity did not cover the greater area in Azerbaijan as compared to today. In the 1930 s, irrigation and land reclamation works in Azerbaijan were less developed than at present, and irrigation channels and collector drainage networks in irrigated areas were rarely found in Azerbaijan. During these years, the depth of groundwater deposition in the Kura-Araz lowland of the republic, including the Shirvan Plain, ranged between 5-10 m (Israfilov, 1972).

The groundwater level gradually begins to rise in the plains where irrigation is carried out. Yet in 1951, the area occupied by groundwater with a depth of 5-10 $\mathrm{m}$ and $10 \mathrm{~m}$ in all irrigated areas decreased from $33 \%$ to $20 \%$. In the Shirvan plain, the areas occupied by groundwater with a depth of 5-10 $\mathrm{m}$ and more than 10 $\mathrm{m}$ decreased by 1.5 times, while the areas covered by groundwater with a depth of $0-3 \mathrm{~m}$ increased by 2.6 times (Israfilov, 1972).

Starting from the 1950s, a new stage of development of land irrigation began in Azerbaijan, and by 1960 , the area of irrigated lands had reached up to 950,000 hectares. Currently, the area of irrigated lands occupies $1.428 \mathrm{~m}$ hectares.

Construction of hydraulic structures, irrigation systems and expansion of irrigated areas gave rise to fundamental changes in the natural regime of groundwater. Within a short period of time, the leakage losses from irrigation channels and the widespread use of intensive surface irrigation have caused the rise of groundwater levels closer to the surface. In 1962, areas covered by groundwater with a depth above $10 \mathrm{~m}$ were almost completely erased from the map. Groundwater with a depth of $0-5 \mathrm{~m}$ covered above $84 \%$ of the Shirvan Plain. With the exception of the foothills of the Shirvan Plain, the groundwater with a depth below 5-10 m was not found. Yet in 1970-1980, groundwater with a depth of $0-3 \mathrm{~m}$ in the Shirvan Plain covered $90 \%$ of the overall area.

The analysis of observational study materials carried out with regard to the groundwater level regime shows that the groundwater level rise continued at different intensities till 1995 and stabilized in the following years. The analysis shows that the stabilization of the groundwater level regime is dependent on two factors:

Construction of collector-drainage networks in irrigated areas;

Increase in the expenditure part of the water balance with the increase of non-productive evaporation from groundwater close to the surface.

The groundwater level regime in the study area - the depth of deposition differs not only over many years, but also throughout the year. The groundwater levels rise up and fall down throughout the year, depending on 
the factors forming the regime-irrigation, atmospheric precipitation and the operation of irrigation channels (seepage losses). The groundwater level rises and falls faster near irrigation channels. The water level in the channel rises and falls synchronously with the groundwater level. The groundwater level is relatively stable in the strips close to the drainage line, but as it moves away from the drainage line, the groundwater level rises in line with the irrigation process, mainly due to infiltration of irrigation water in the interdrainage strips, and gradually decreases after irrigation is suspended.

Observations show that the groundwater level regime is dependent insignificantly on atmospheric precipitation. The groundwater deposition level is deeper at different times of the year, mainly when the rainfall occurs in autumn-winter. As a rule, the groundwater level begins to rise gradually from April, and the maximum amplitudes of the level are observed in July-August. From October to January, the level drops. In areas with a groundwater depth exceeding 3 $\mathrm{m}$, the level does not rise significantly. The value of the rise and fall amplitude very rarely varies between $0.3-$ $0.6 \mathrm{~m}$. However, in areas irrigated and close to irrigation channels, the amplitude of groundwater level change comprises $0.7-1.0 \mathrm{~m}$, and in some cases even more.

Due to water losses from irrigation channels and infiltration from irrigation, the hydrogeological conditions of the area have changed and the automorphic regime of groundwater has been replaced by hydromorphic and semi-automorphic regimes. The balance of groundwater has been formed to determine the impact of anthropogenic activity and natural factors on the level and hydrochemical regime of groundwater, as well as the regularities of their formation (Jafarli 2020).

According to the water balance compiled, it was determined that $10 \%$ of the balance income refers to irrigation water, $7 \%$ - atmospheric sediments, $35 \%-$ pressurized water, $26 \%$ - condensation water, and $22 \%$ seepage losses from irrigation channels.

Total evaporation comprises $63 \%$ of the balance output, and $37 \%$ comprises water discharged through collector-drainage networks.
$63 \%$ of the water inflowing to the area is used for physical evaporation and transpiration by plants, and $37 \%$ is discharged from the area through collectordrainage networks. The groundwater level regime is determined according to these factors. That is, in general, the water entering the area is compensated by evaporation and artificial flow.

One important point to note is that the experience of irrigated agriculture shows that re-salinization of soils occurs due to rising groundwater levels and increased physical evaporation from the soil. Therefore, there is a need to establish a collector-drainage network in irrigated areas.

The compiled balance also indicates that the operation of the collector-drainage network operating in the area is unsatisfactory. Physical evaporation against the background of drainage should be kept to a minimum. But we see otherwise in practice. Therefore, it is necessary to increase the efficiency of existing collector-drainage networks in Shirvan Plain.

Although the amount of condensate water is high in mountainous areas and low in lowland areas, they play a key role in forming the groundwater level and its chemical regime.

In line with the above-mentioned, it was determined that the groundwater is fed by pressurized water throughout the year, which plays an important role in raising the groundwater level, as well as the formation of the hydrochemical regime. Despite rising groundwater levels, their degree of mineralization and chemical composition vary depending on available supply sources. For example, irrigation and condensation water, seepage losses from channels, along with raising the level of groundwater, lead to a gradual decrease in their salinity.

The information on the groundwater chemical regime is systematized and reflected in Table 1 according to the literature sources, research work we conducted and the reports of Azerbaijan Hydrogeological and Melioration Service for the period 1990-2018 (Aliyev et 1., 1990).

Table 1. Distribution of the areas according to mineralization degree of subsoil waters (by \% from total area)

\begin{tabular}{|c|c|c|c|c|c|c|c|c|c|}
\hline \multirow{2}{*}{ Years } & \multicolumn{8}{|c|}{ Mineralization degree of subsoil waters } & \multirow{2}{*}{$\begin{array}{c}\text { Average Mineralization } \\
\text { degree, } q / l\end{array}$} \\
\cline { 2 - 9 } & $<1$ & $1-3$ & $3-5$ & $5-10$ & $10-25$ & $25-50$ & $50-75$ & $>75$ & 26.8 \\
\hline 1930 & 6.3 & 8.6 & 13.1 & 16.0 & 15.3 & 15.9 & 13.9 & 12.9 & 31.5 \\
\hline 1950 & 4.2 & 6.3 & 9.4 & 14.9 & 17.3 & 18.1 & 15.2 & 14.6 & 34.5 \\
\hline 1960 & 6.7 & 8.5 & 9.7 & 15.1 & 17.1 & 15.9 & 14.8 & 12.2 & 33.6 \\
\hline 1970 & 8.8 & 9.9 & 11.3 & 15.3 & 16.3 & 15.4 & 13.2 & 9.8 & 22.9 \\
\hline 1980 & 10.5 & 12.5 & 12.6 & 15.6 & 15.5 & 14.7 & 10.4 & 8.2 & 19.8 \\
\hline 1990 & 12.6 & 15.7 & 13.3 & 15.8 & 14.8 & 11.6 & 9.8 & 5.4 & 17.2 \\
\hline 2000 & 14.7 & 16.9 & 14.8 & 16.1 & 14.6 & 11.2 & 5.9 & 4.8 & 16.1 \\
\hline 2010 & 18.4 & 17.5 & 15.6 & 16.2 & 13.3 & 11.4 & 6.6 & 3.9 & 15.1 \\
\hline 2018 & 14.3 & 18.6 & 15.0 & 16.7 & 14.4 & 11.5 & 6.3 & 4.2 & \\
\hline
\end{tabular}


As seen from Table 1 the average mineralization degree of subsoil waters was $26,8 \mathrm{~g} / \mathrm{l}$ in the zone in 1930. But the mineralization rate of subsoil waters began to increase beginning from 1950 and this growth continued till 1970. In 1960-1970 the subsoil waters with 33,6-34,5 g/1 mineralization degree occupied about $70 \%$ of the whole zone. But then the mineralization degree began to decrease gradually and in 2000 it passed to a stage of relative stabilization. The subsoil waters with mineralization rate less than $5 \mathrm{~g} / 1$ occupied $28 \%$ of the zone in 1930 , but in 2018 the waters with mineralization degree less than $5 \mathrm{~g} / 1$ occupied $48 \%$ of the zone (Table 1).

Increase-decrease of mineralization degree of subsoil waters was directly related to anthropogenic activity. Beginning from 1950 irrigation agriculture quickly developed in Azerbaijan. In 1953 the Mingachevir Water Reservoir with 80m height, 60,5000 $\mathrm{h}$ of surface area, 16 billion $\mathrm{m}^{3}$ of total water capacity and dozens of reservoirs of water of water capacity of more than 1-10 billion $\mathrm{m}^{3}$ were built for the purpose of irrigation and energetics (Ahmedzade and Hashimov 2019). At the same time, construction of large irrigation systems was carried out to provide the sown areas with irrigative water. In 1958 the Upper Shirvan Channel with $122 \mathrm{~km}$ length, capacity of $78 \mathrm{~m}^{3}$ and taking its beginning from Mingachevir Water Reservoir, the Upper Garabagh canal with capacity of $113 \mathrm{~m}^{3}, 172 \mathrm{~km}$ length were built and put into operation (Ahmedzade and Hashimov 2006). These canals are able to provide $190000 \mathrm{~h}$ of cultivated ground with irrigation water. The irrigation water taken from the main channels is distributed to the sown areas by inter-farm and on-farm canals the length of which is more than $10,000 \mathrm{~km}$. As both main and other distribution channels are built in the soil, the leaching from these canals can lead to a change in their level regime, including groundwater in irrigated areas. According to the groundwater level regime, groundwater levels of reach more than 5-10 meters depth and closer to the earth's surface. In $70 \%$ of all irrigated areas the groundwater depth is $0-3 \mathrm{~m}$ (Israfilov, 1972). The subsoil water near the earth's surface is subjected to severe evaporation. Consequently, increase in the groundwater mineralization process occurs in irrigated soil.

In 1950-1970 in order to prevent secondary salinization in the Shirvan Plain and to fight against it, 29 Shirvan drainage networks in an area of 209,000 ha and the Main Shirvan Collector which sheds drainage water into the Caspian Sea were built (Ahmedzade and Hashimov 2006). As a result, salts leached from the topsoil enter groundwater and increase their salinity. However, in the following years, as a result of thorough washing of soils, which lasted for about 20 years, the operation of collector-drainage networks and intensive irrigation, the mineralization rate of groundwater began to gradually decrease. We should note that the plants in this zone are watered by the strip, burial, furrow techniques. This leads to increase of water losses.

In order to define a change tendency of the chemical regime and formation of regularities of subsoil water, the changes in the chemical composition and mineralization of water in the Main Shirvan Collector have been studied. Change in the chemical regime of water in the Main Shirvan Collector taking subsoil water from 253,000 ha permits us to obtain more substantial information about change and formation of the chemical regime in grounwater.

The study of this problem is also of practical importance in terms of determining accessibility of collector water for irrigation, technical and other purposes in times of water defficiency. We note for information that systematic and consistent observation on chemical regime of the Main Shirvan Collector water has been carried out beginning from 2010. Only in 1995 was the chemical composition and mineralization of waste water was studied for the Main Shirvan and other collectors to determine the possibility of collector water use, (Alimov et al., 1997). Therefore the infomation was adopted.

The dynamics of chemical composition and mineralization rate in water of the Main Shirvan Collector are presented in Table 2.

As seen from Table 2 the mineralization rate of the collector water decreased about 3 times during 23 years. But the water type doesn't change. Both in 1995 and in 2018 the collector water is characterized by sulphatechlorine, natrium-magnesium type.

But the mineralization rate of the Main Collector water is 2-2.5 times less than the mineralization degree of groundwater (water taken from observation wells).

This difference is explained by the fact that during the vegetation period one part of the drinkable water that flows though the irrigation channels enters the bottom of the soil. The drinkable water layer is formed on upper horizons of subsoil water. This drinkable water is filtered into the first drains, from there it flows into the water collectors. At the same time the water having the highest mineralization degree enters the collector drainage network from low layers of groundwater. Consequently, the chemical regime of the collectordrainage water is formed from irrigation and subsoil water.

1. The anthropogenic activity plays an important role in formation of the chemical regime in groundwater.

2 . The chemical regime of groundwater in the relative stabilization phase. The mineralization rate decreased more than 2 times in comparison with the 1930s-70s. 
Table 2. Mineralization rate $(q r / l)$ and and chemical composition, $m q / l / m q-e k v$, \%-ekv

\begin{tabular}{|c|c|c|c|c|c|c|c|}
\hline \multirow[b]{2}{*}{ Years } & \multirow{2}{*}{$\begin{array}{l}\text { Mineralization rate } \\
\text { (dry resiidue), } m q / l\end{array}$} & \multicolumn{3}{|c|}{ Anions } & \multicolumn{3}{|c|}{ Cations } \\
\hline & & $\mathrm{HCO}_{3}^{-}$ & $\mathrm{Cl}^{-}$ & $\mathrm{SO}_{4}^{2-}$ & $\mathrm{Ca}^{2+}$ & $\mathrm{Mg}^{2+}$ & $\mathrm{Na}^{+}+\mathrm{K}^{+}$ \\
\hline 2010 & 4.85 & $\begin{array}{l}\frac{427}{7.00} \\
9.24 \\
\end{array}$ & $\begin{array}{l}\frac{1012}{28.50} \\
37.64\end{array}$ & $\begin{array}{l}1931 \\
40.22 \\
53.12\end{array}$ & $\begin{array}{c}\frac{230}{11.50} \\
15.18\end{array}$ & $\begin{array}{l}\frac{252}{21.00} \\
27.74\end{array}$ & $\begin{array}{l}\frac{994}{43.22} \\
57.08\end{array}$ \\
\hline 2011 & 3.80 & $\begin{array}{c}\frac{397}{6.50} \\
19.72\end{array}$ & $\begin{array}{l}\frac{888}{25.01} \\
41.71\end{array}$ & $\begin{array}{l}\frac{1366}{28.45} \\
47.47\end{array}$ & $\begin{array}{c}\frac{170}{8.50} \\
14.18\end{array}$ & $\begin{array}{l}\frac{222}{18.50} \\
30.85\end{array}$ & $\begin{array}{l}\frac{758}{32.96} \\
54.97\end{array}$ \\
\hline 2012 & 2.95 & $\begin{array}{l}\frac{366}{6.00} \\
12.57 \\
\end{array}$ & $\begin{array}{l}\frac{888}{25.00} \\
52.37 \\
\end{array}$ & $\begin{array}{c}\frac{804}{16.74} \\
35.06\end{array}$ & $\begin{array}{c}\frac{190}{9.50} \\
19.90\end{array}$ & $\begin{array}{l}\frac{198}{16.50} \\
34.56 \\
\end{array}$ & $\begin{array}{l}\frac{500}{21.74} \\
45.54\end{array}$ \\
\hline 2013 & 3.09 & $\begin{array}{c}\frac{336}{5.51} \\
11.33\end{array}$ & $\begin{array}{l}\frac{728}{20.51} \\
42.16\end{array}$ & $\begin{array}{l}\frac{1086}{22.63} \\
46.51\end{array}$ & $\begin{array}{c}\frac{180}{9.00} \\
18.50\end{array}$ & $\begin{array}{l}\frac{168}{14.00} \\
28.78\end{array}$ & $\begin{array}{c}\frac{590}{25.65} \\
52.72\end{array}$ \\
\hline 2014 & 2.51 & $\begin{array}{l}\frac{275}{4.50} \\
11.21 \\
\end{array}$ & $\begin{array}{l}\frac{657}{18.50} \\
46.08\end{array}$ & $\begin{array}{l}\frac{823}{17.15} \\
42.71 \\
\end{array}$ & $\begin{array}{l}\frac{60}{3.00} \\
7.47 \\
\end{array}$ & $\begin{array}{l}\frac{174}{14.50} \\
36.11 \\
\end{array}$ & $\begin{array}{c}\frac{521}{22.65} \\
56.42\end{array}$ \\
\hline 2015 & 2.01 & $\begin{array}{c}\frac{275}{4.51} \\
13.70\end{array}$ & $\begin{array}{l}\frac{497}{14.00} \\
42.54\end{array}$ & $\begin{array}{c}\frac{691}{14.40} \\
43.76\end{array}$ & $\begin{array}{c}\frac{100}{5.00} \\
15.19\end{array}$ & $\begin{array}{c}\frac{216}{18.00} \\
54.70\end{array}$ & $\begin{array}{c}\frac{228}{9.91} \\
30.11\end{array}$ \\
\hline 2016 & 1.85 & $\begin{array}{c}\frac{282}{4.63} \\
16.58\end{array}$ & $\begin{array}{c}\frac{257}{7.24} \\
25.92\end{array}$ & $\begin{array}{l}\frac{771}{16.06} \\
57.50\end{array}$ & $\begin{array}{c}\frac{105}{5.25} \\
18.80\end{array}$ & $\begin{array}{c}\frac{99}{8.25} \\
29.54\end{array}$ & $\begin{array}{l}\frac{332}{14.43} \\
51.66\end{array}$ \\
\hline 2017 & 2.15 & $\begin{array}{c}\frac{305}{5.00} \\
15.29\end{array}$ & $\begin{array}{c}\frac{284}{8.00} \\
24.46\end{array}$ & $\begin{array}{l}\frac{946}{19.71} \\
60.25\end{array}$ & $\begin{array}{c}\frac{110}{5.50} \\
16.80\end{array}$ & $\begin{array}{l}\frac{138}{11.50} \\
35.16\end{array}$ & $\begin{array}{l}\frac{362}{15.71} \\
48.03\end{array}$ \\
\hline 2018 & 2.51 & $\begin{array}{l}\frac{336}{5.50} \\
14.55\end{array}$ & $\begin{array}{c}\frac{337}{9.49} \\
25.11\end{array}$ & $\begin{array}{l}\frac{1095}{22.81} \\
60.34\end{array}$ & $\begin{array}{c}\frac{170}{8.50} \\
22.49\end{array}$ & $\begin{array}{c}\frac{108}{9.00} \\
23.81\end{array}$ & $\begin{array}{l}\frac{467}{20.30} \\
53.70\end{array}$ \\
\hline
\end{tabular}

3. The chemical regime of groundwater is formed as a result of the collector-drainage network and water losses in irrigation canals including anthropogenic activity in the arid zone (in the regions where evaporation is $3-5$ times more than rainfall). Therefore regulation of these factors and management in a good condition is one of the important terms.
4. The mineralization rate of the Main Shirvan Collector water which is taken from the research zone and available collector-drainage networks and flows into the Caspian Sea decreased more than 3 times and this reduction tendency weakly develops. Formation of a suitable chemical regime creates an opportunity to use from collector water for irrigation, technical and other aims in drought years and under conditions of the water defficiency.

\section{References}

Abbasov, F.M., 2009. Azərbaycan Respublikası Ekologiya və Təbii Sərvətlər Nazirliyinin Milli Geoloi Kəşfiyyat Xidmətinin Kompleks Hidrogeologiya və Mühəndis Geologiya Ekspedisiyasının «2004-2008-ci illərdə Girdimançay-Göyçayarası sahəsində içməli yeraltı şirin su ehtiyatlarının ilkin qiymətləndirilməsi işlərinin nəticələri haqqunda Hesabat».[Report on the results of the preliminary assessment of drinking groundwater resources in the Girdimanchay-Goychayarasi area of the Complex Hydrogeology and Engineering Geology Expedition of the National Geological Survey of the Ministry of Ecology and Natural Resources of the Republic of Azerbaijan in 2004-2008] Baku. (In Azerbaijani).

Abbasov, F.M., 2013. Azərbaycan Respublikası Ekologiya və Təbii Sərvətlər Nazirliyinin Milli Geoloi Kəşfiyyat

Xidmətinin Kompleks Hidrogeologiya və Mühəndis Geologiya Ekspedisiyasının «2009-2012-ci illərdə Türyançay gətirmə konusunda yeraltı şirin su qaynaqlarının axtarışı işlərinin nəticələri haqqında Hesabat» [Report on the results of the search of groundwater sources in the Turyanchay delivery area of the Complex Hydrogeology and Engineering Geology Expedition of the National Geological Survey of the Ministry of Ecology and Natural Resources of the Republic of Azerbaijan in 2009-2012.] (In Azerbaijani).

Ahmedzade, A.C., Sadigov. S.T, Amishov. Sh. M. Pambıqçılığın inkişafi ilə əlaqədar Kür-Araz ovalığının hidrigeoloji-meliorativ vəziyyətinin qiymətləndirilməsi və tənzimlənməsi [Assessment and regulation of hydro-ameliorative condition of Kur- 
Araz lowland in connection with development of cotton growing] Baku (In Azerbaijani).

Ahmedzade, A.J., Hashimov, A.J., 2019. Ensiklopediya: Azərbaycan meliorasiya və su təsərrüfat1 [Encyclopedia: Azerbaijan amelioration and water economy. Baku. (In Azerbaijani).

Ahmedzade, A.J., Hashimov, A.J., 2006. Meliorasiya və su təsərrüfatı sistemlərinin kadastr1 [Cadastre of amelioration and water management systems]. Baku (In Azerbaijani).

Alimovm, A.K., 1997. Baku Ocenka i prognoz kachestva kollektorno-drenazhnyh vod i vozmozhnosti ispolzovaniya ih $\mathrm{v}$ narodnom hozyajstve. [Assessment and forecast of the quality of collector-drainage waters and the possibility of using them in the national economy.] (In Russian).

Alimov, A.K., Magomedov, A.M., Mailov, Y.Q., 1995. Gidrogeologicheskie osnovy regulirovaniya vodnosolevogo rezhima oroshaemyh zemel aridnoj zony. [Hydrogeological bases of regulation of watersalt regime of irrigated lands in arid zone.]. Baku (In Russian).

Aliyev, A.Q., Shabanov, A.I., Qovrilov, V.M., Informaciya o gidrogeologo-meliorativnom sostayaniie oroshaemyh zemel Azerbajdzhanskoj SSR [Information on the hydrogeological-reclamation state of the irrigated lands of the Azerbaijan SSR] (In Russian).

Behbudov, A.K., Jafarov, X.F., 1980. Melioraciya zasolyonyh zemel. [Reclamation of saline soils.] (In Russian).

Behbudov, A. K., 1977. Eksperimentalnye osnovy provedeniya melioracii zasolennyh zemel KuraAraksinskoj nizmennosti. [Experimental basis for reclamation of saline lands in the Kura-Araks lowland.] (in Russian).

Gulmamedov Ch.D., Jafarli J. V. 2019 Rezhim podzemnyh vod Shirvanskoj stepi Azerbajdzhanskoj Respubliki // Nauka i Mir. [Groundwater regime of the Shirvan steppe of the Azerbaijan Republic. Science and World (In Russian).

Israfilov, Y.Q., 1999. Konceptual'naya model' formirovaniya podzemnyh vod Azerbajdzhanskoj Respubliki. V kn.: Materialy nauchno-prakticheskoj konfrencii. AzNII VP «Voda: problemy, poiski». [Conceptual model of the formation of groundwater in the Azerbaijan Republic. In the book: Materials of scientific-practical conference. ARI «Water: problems, searches».] Baku (In Russian).

Israfilov, Y.Q., 1972. Gruntovye vody Kura-Araksinikij nizmennosti. [Ground waters of the Kura-Araksinikiy lowland] Baku. (In Russian).

Israfilov, Y.Q., 1965. Baku. Izmenenie himicheskogo sostava i mineralizacii poverhnostnogo sloya gruntovyh vod Kura-Araksinskoj nizmennosti. Uchenye zapiski Azgosuniversiteta. [Changes in the chemical composition and mineralization of the surface layer of groundwater in the Kura-Araz lowland. Scientific notes of the Azerbaijan State University].(In Russian).

Jafarli, J.V., 2020. Türyançay-Girdimançay çaylararası ərazinin qrunt sualrı və onların formalaşma qanunauyğunluqları. AzETHvəMİ EİB-nin elmi əsərlər toplusu. [Soil question of Turyanchay-Girdimanchay inter-river area and regularities of their formation. Collection of scientific works] (In Azerbaijani).

Namazov, I. Sh., Allahverdiyeva, F.F. 2014. Azərbaycan Respublikasının su təsərrüfatı sahələri üzrə suların keyfiyyətinə dair çoxillik məlumatlar.[Multiple information on water quality in the water resources of the Republic of Azerbaijan.] Baku. (In Azerbaijani).

Azərbaycan Geologiya İdarəsinin fond materialları. Bak1: 1981-1989-cu illor [Fund materials of the Azerbaijan Geological Department. Baku: 1981-1989]. (In Azerbaijani).

Azərbaycan Meliorasiya Su Təsərrüfatı ASC-nin Hidrogeoloji-Meliorativ Xidmət İdarəsinin hesabatları. [Reports of Hydrogeological-Ameliorative Service Department of Azerbaijan Melioration Water Management OJSC] Baku 2010-2018. (In Azerbaijani). 